ISSN 1392-3196 / e-ISSN 2335-8947

Zemdirbyste-Agriculture, vol. 105, No. 1 (2018), p. 63-70

DOI 10.13080/z-a.2018.105.009

\title{
Agro-industrial tomato by-products and extraction of functional food ingredients
}

\author{
Dalia URBONAVIČIENE $\dot{E}^{1}$, Ramunè BOBINAITE $\dot{E}^{1}$, Sonata TRUMBECKAITE் ${ }^{2,3}$, \\ Lina RAUDONE ${ }^{2}$, Valdimaras JANULIS ${ }^{2}$, Česlovas BOBINAS ${ }^{1}$, Pranas VIŠKELIS ${ }^{1}$ \\ Institute of Horticulture, Lithuanian Research Centre for Agriculture and Forestry \\ Kauno 30, Babtai, Kaunas distr., Lithuania \\ E-mail: d.urbonaviciene@1sdi.lt \\ ${ }^{2}$ Medical Academy, Lithuanian University of Health Sciences \\ Eivenių 4, Kaunas, Lithuania \\ ${ }^{3}$ Neuroscience Institute, Lithuanian University of Health Sciences \\ Eivenių 4, Kaunas, Lithuania
}

\begin{abstract}
Agro-industrial by-products are important sources of functional food ingredients with commercial interest to decrease the volume of by-products and also to improve the economic viability of processes, by producing added value ingredients. For this purpose, application of the supercritical carbon dioxide $\left(\mathrm{SC}-\mathrm{CO}_{2}\right)$ technology to add value to tomato (cultivar 'Admiro' F1) by-products (peel, seeds and small amount of pulp) was tested. Optimisation of extraction parameters of high value-added ingredients (oleoresin with $60 \%$ cis-lycopene isomers concentration) was carried out and antioxidant effect of extract in cell culture was analysed.

The extract obtained at optimised conditions $\left(52^{\circ} \mathrm{C}\right.$ temperature, a $55 \mathrm{MPa}$ pressure and a 180 min extraction time), was characterized for total lycopene and lycopene different isomers (15-cis-lycopene, 13-cis-lycopene, 9-cislycopene, 7-cis-lycopene, trans-lycopene and 5-cis-lycopene) and the antioxidant effect of extracts was evaluated by assessing the production of the reactive oxygen species (ROS) by murine macrophage J774 cell culture.

Results showed that the $\mathrm{SC}-\mathrm{CO}_{2}$ extracts of tomato by-products (peel, seeds and small amount of pulp) is a potential source of cis-lycopene isomers (the total content of cis-lycopene isomers in the $\mathrm{SC}-\mathrm{CO}_{2}$ extract was $60 \%$ ) oleoresin with promising applications in food and pharmaceutical industries.
\end{abstract}

Key words: antioxidant, lipophilic extract, lycopene, Lycopersicon esculentum, trans/cis-isomers.

\section{Introduction}

The industrial processing of tomato (Lycopersicon esculentum Mill.) fruits into tomato products generates large amounts of by-products (peel, pulp and seeds). These by-products create major disposal problems for the industry in terms of costs and potential negative impact on the environment, but they also represent a promising, low-cost source of carotenoids (primarily lycopene) which may be used in the end-products because of their favourable nutritional and technological properties (Silva et al., 2014). The human diet can help reduce the risk of certain diseases and improve the quality of life (Korhonen, 2002; Kaur, Das, 2011). These concepts have led to the introduction of a new category of health-promoting foodstuffs, i.e.

functional food. Functional food is "any fresh or processed food that is claimed to have a health promoting and/or disease-preventing property beyond the basic nutritional functions of supplying nutrients" (Kaur, Das, 2011). The demand for information about functional food has increased. These foods may help prevent diseases, reduce the risk of developing a disease or enhance health (Kaur, Das, 2011). Fruits and vegetables have a wide range of various phytochemicals that may provide different health benefits (Shahidi, 2009; Viskelis et al., 2010). Scientists are trying to assess the biological activities of different phytochemicals found in fruits and vegetables to fabricate different functional foods (Bruno et al., 2007; Granato et al., 2010; Urbonavičienė et al., 2015).

Please use the following format when citing the article:

Urbonavičienė D., Bobinaitė R., Trumbeckaitė S., Raudonė L., Janulis V., Bobinas Č., Viškelis P. 2018. Agro-industrial tomato byproducts and extraction of functional food ingredients. Zemdirbyste-Agriculture, 105 (1): 63-70 DOI 10.13080/z-a.2018.105.009 
Humans are not capable of synthesizing lycopene de novo which implies that the amount of lycopene available for metabolic functions in the human body depends on the lycopene content in the food products consumed. It is important to highlight the fact that the absorption of lycopene from dietary sources occurs within the range of $10 \%$ to $30 \%$ in humans. Consequently, lycopene uptake is never complete and more than $70 \%$ will not be absorbed (Colle et al., 2010; Holzapfel et al., 2013). The biological activity of cis-lycopene isomers is different from the all-trans-isomers. It has been well documented that cis-lycopene is more bioavailable than trans-lycopene in vitro and in vivo probably because cis-isomers are more soluble in bile acid micelles and may be preferentially incorporated into chylomicrons (Fernández-García et al., 2012). Therefore, it is desirable to develop products with increased cis-lycopene content. The isomerization of lycopene is influenced by various technological processes and factors such as temperature, light (Urbonaviciene et al., 2017), supercritical $\mathrm{CO}_{2}$ (Urbonaviciene, Viskelis, 2017).

The biochemical reactions that take place in the cells and organelles of human body support normal vital functions. Internally, free radicals are produced as a normal part of metabolism within the mitochondria, peroxisomes, inflammation processes, phagocytosis, arachidonate pathways, ischemia and physical exercise. The external factors that promote the production of free radicals, especially reactive oxygen species (ROS), are smoking, environmental pollutants, radiation, pesticides and industrial solvents (Lobo et al., 2010). In normal cellular metabolism, oxygen derivatives are neutralized or eliminated owing to the presence of a natural defence mechanism that involves enzymatic antioxidants (glutathione peroxidase, superoxide dismutase and catalase) and water or fat-soluble nonenzymatic antioxidants (biologically active compounds). The disturbed balance between production of ROS and their elimination leads to a state known as oxidative stress that induces damage to the DNA, proteins and lipids (Wiernsperger, 2003). Nicotinamide adenine dinucleotide phosphate (NADPH) oxidases are the only enzymes whose primary function is to generate ROS, which are toxic to pathogens, but also may damage the surrounding normal tissues and cells, causing various abnormalities, such as infection, arteriosclerosis, neurodegenerative diseases and inflammation. Biologically active compounds of plant origin have antiinflammatory properties, although the mechanisms of their action are not yet fully understood.

Extraction applying novel processing technologies such as supercritical fluid extraction is developing fast due to the increasing consumer demand for clean and green extraction techniques with minimal use of organic solvents. In addition, supercritical carbon dioxide $\left(\mathrm{CO}_{2}\right)$ has higher selectivity for extraction of some value added ingredients from various plant materials including agro-industrial by-products (Lenucci et al., 2010; Perretti et al., 2013; Silva et al., 2014). Despite considerable research focused on the supercritical carbon dioxide $\left(\mathrm{SC}-\mathrm{CO}_{2}\right)$ extraction of tomato by-products, deeper knowledge concerning lycopene extracts and their biological activities is still lacking. Some studies have demonstrated the efficacy of $\mathrm{SC}-\mathrm{CO}_{2}$ for the extraction of lycopene from tomatoes. However, only the effect of few SC extraction parameters on the total yield of lycopene and carotenoids from tomatoes and tomato by-products, have been described (Lenucci et al., 2010; Perretti et al., 2013; Azabou et al., 2016). In addition, most studies focused on the amount of total lycopene extracted, whereas composition of lycopene isomers was not characterized. Different parameters of $\mathrm{SC}-\mathrm{CO}_{2}$ extraction can have individual or combined effects not only on the total extraction yield of lycopene but also on the composition of the extract obtained. Most commonly, in experiments with cells, oxidative damage induced by hydrogen peroxide $\left(\mathrm{H}_{2} \mathrm{O}_{2}\right)$ is measured after preincubation of cells (of various types) with carotenoids, but not with lycopene, especially with cis-isomers (LinnewielHermoni et al., 2015; Kumar et al., 2013). Despite extensive studies on the biological activities of lycopene cis-isomers, detailed information about the antioxidant activities of $\mathrm{SC}-\mathrm{CO}_{2}$ cis-lycopene extracts is limited.

The aim of this study was to evaluate the composition of the $\mathrm{SC}-\mathrm{CO}_{2}$ cis-lycopene extract from tomato by-products and the antioxidant effect of extracts by assessment of the production of the reactive oxygen species (ROS) by murine macrophage $\mathrm{J} 774$ cell culture.

\section{Materials and methods}

Materials. The experiments were carried out in 2016-2017 at the Laboratory of Biochemistry and Technology of the Institute of Horticulture, Lithuanian Research Centre for Agriculture and Forestry and at the Neuroscience Institute, Lithuanian University of Health Science.

The following analytical grade chemicals were used: hexane (Carl Roth $\mathrm{GmbH}$, Karlsruhe, Germany), acetone (Stanchem, Poland), MTT (3-(4,5-dimethylthiazol-2-yl)-2,5-diphenyltetrazolium bromide), dimethylsulfoxide (DMSO), Hoechst 33342, propidium iodide (PI), 2',7'-dichlorofluorescin diacetate (DCHF-DA), phorbol 12-myristate 13-acetate and arachidonic acid ("Sigma", USA), phosphate-buffered saline(PBS)(“Sigma”), horseradishperoxidase("Sigma”), Amplex Red ("Sigma”), Dulbecco's modified Eagle's medium (DMEM) (Thermo Fisher Scientific, USA). The HPLC-grade solvents, including hexane, methanol, methyl-tert-butyl ether, tetrahydrofuran and isopropanol were obtained from Sigma-Aldrich (Germany), methanol and methyl tert-butyl ether as HPLC solvents were purchased from Sigma-Aldrich (HPLC grade $\geq 99.8 \%$ ) and trans-lycopene (HPLC-grade, all-trans-lycopene, from tomato, powder) standard was from Sigma-Aldrich. Carbon dioxide (99.9\%) was obtained from "Gaschema" (Jonava distr., Lithuania). 
Sample preparation. Fully ripe red tomato (Lycopersicon esculentum Mill., cultivar 'Admiro' F1) was used in this study. Fruit was washed, dried and processed. The tomato juice with pulp was separated from seeds and peels. By-products (peels, vascular tissues, seeds and small amounts of pulp) of tomatoes of 'Admiro' F1 were freeze-dried using a freeze-dryer FD8512S (ilShin ${ }^{\circledR}$ Europe, The Netherlands) and were ground to a powder using a knife mill GM200 (Retsch, Germany). The powder was weighed immediately after collection and refrigerated at $-20^{\circ} \mathrm{C}$ prior to the extraction with $\mathrm{SC}-\mathrm{CO}_{2}$.

Supercritical fluid extraction with $\mathrm{CO}_{2}$. The supercritical carbon dioxide $\left(\mathrm{SC}-\mathrm{CO}_{2}\right)$ experiments were carried out using supercritical fluid extractor SFT-150 (Supercritical Fluid Technologies, USA). Each extraction was performed using a $15 \mathrm{~g}$ sample of ground freezedried tomato by-products. Each sample was loaded into a $500 \mathrm{~mL}$ thick-walled stainless steel cylindrical extractor vessel with an inner diameter of $14 \mathrm{~mm}$ and a length of $320 \mathrm{~mm}$. To avoid system clogging, the sample was placed between two layers of cotton wool. The temperature of the extraction vessel was controlled using a surrounding heating jacket. The volume of $\mathrm{CO}_{2}$ consumed was measured by a ball float rotameter and a digital mass flow meter in standard litres per minute (SL $\left.\mathrm{min}^{-1}\right)$ at standard state $\left(\mathrm{P}_{\mathrm{CO} 2}=100 \mathrm{kPa}, \mathrm{T}_{\mathrm{CO} 2}=20^{\circ} \mathrm{C}\right.$, $\left.\rho_{\mathrm{CO} 2}=0.0018 \mathrm{~g} \mathrm{~mL}^{-1}\right)$. The process consisted of static (10 min) and dynamic extraction steps. The static extraction time was included in the total extraction time.

The extracts were collected in amber glass flasks and cooled in an ice bath. The collected extracts were kept at $-22^{\circ} \mathrm{C}$ until analysis. Lycopene and its cis-isomer content in extracts from tomato by-products were determined using HPLC.

Extraction of carotenoids. The total lycopene content was determined according to Poojary and Passamonti (2015) with slight modification. The sample $(1.0 \mathrm{~g})$ was extracted repeatedly with $30 \mathrm{~mL}$ of acetone in $\mathrm{n}$-hexane $(1: 3 \mathrm{v} / \mathrm{v})$ for $15 \mathrm{~min}$ each time until the absorbance of the extract at $503 \mathrm{~nm}$ was lower than the instrumental noise $(0.5 \mathrm{mAU})$. These extracts were combined and the total lycopene content (considered as $100 \%$ yield) was analysed using HPLC.

High-performance liquid chromatography (HPLC) analysis of lycopene and its isomers. The extracts and freeze-dried powder was prepared for HPLC analysis. For analysis $0.1 \mathrm{~g}$ of oleoresins after $\mathrm{SC}-\mathrm{CO}_{2}$ extraction was dissolved in $10 \mathrm{ml}$ hexane and tetrahydrofuran with $1 \%$ butylated hydroxytoluene (BHT) solution $(4: 1 \mathrm{v} / \mathrm{v})$. The HPLC system used was a liquid separation module Waters 2695 ("Waters", USA). Elution of materials was monitored by 2489 UV-Visible (UV-Vis) detector ("Waters"). Detection of lycopene was $473 \mathrm{~nm}$. The lycopene cis-isomers for photo array PAD 2998 ("Waters") analysis detection were from 200 to $600 \mathrm{~nm}$. Chromatographic separations were performed on a RP-C30 column $5 \mu \mathrm{m}, 250 \times 4.0 \mathrm{~mm}$ (YC-Europe $\mathrm{GmbH}$, Germany) connected to a $\mathrm{C} 30$ guard column
$5 \mu \mathrm{m}, 10 \times 4.0 \mathrm{~mm}$ (YC-Europe) using a flow rate of 0.65 $\mathrm{mL} \mathrm{min}^{-1}$. The chosen column temperature was $25^{\circ} \mathrm{C}$. The mobile phase used consisted of methanol (solvent A) and methyl-tert-butyl ether (solvent B). Samples were injected at $40 \% \mathrm{~B}$ (held $5 \mathrm{~min}$ ), and the gradient then changed to $83 \% \mathrm{~B}$ in $50 \mathrm{~min}$. Then the gradient changed to $100 \% \mathrm{~B}$ in $5 \mathrm{~min}$ (held $10 \mathrm{~min}$ ) and to $40 \% \mathrm{~B}$ in $5 \mathrm{~min}$ (held $10 \mathrm{~min}$ ) (Fig. 1). High-performance liquid chromatography was performed using a modified version (Urbonavičienè et al., 2015) of the different methods and systems described by Heymann et al. (2013). Levels of cis-lycopene isomers are given in all-trans-lycopene equivalents.

Colour measurements. The colour of extracts was measured by a spectrophotometer MiniScan XE Plus (Hunter Associates Laboratory Inc., USA) following the method of McGuire (1992), with slight modifications. The apparatus (45/0 geometry, illuminant D65, 10 observer) was calibrated with a standard tile $(\mathrm{X}=81.3$, $\mathrm{Y}=86.2, \mathrm{Z}=92.7)$. A cylindrical glass cell filled with 3 $\mathrm{mL}$ of sample was placed on the top of the light source (2.5 cm opening) and covered with a white plate. The inclusion of air bubbles was prevented. The recorder $X$, $\mathrm{Y}$ and $\mathrm{Z}$ tristimulus values were converted to CIE $L^{*}, a^{*}$ and $b^{*}$ colour values. Regarding light reflection, the $L^{*}$, $a^{*}$ and $b^{*}$ parameters (lightness, redness and yellowness indices, respectively, according to CIE $L^{*} a^{*} b^{*}$ scale) were measured, the chroma $\left(\mathrm{C}=\left(a^{* 2}+b^{* 2}\right)^{1 / 2}\right)$ and hue angle $\left(\mathrm{h}^{\circ}=\arctan \left(b^{*} / a^{*}\right)\right)$ were calculated. The colour parameters were processed with the software Universal V.4-10. Colour measurements were performed in triplicate.

Cell culture. Murine macrophage cells of J774 (Lines Service $\mathrm{GmbH}$, Germany) were used for the experiments. Murine macrophage cells of J774 were maintained in DMEM $+10 \%$ fetal calf serum + penicillin $\left(100 \mathrm{U} \mathrm{mL}^{-1}\right) /$ streptomycin $\left(100 \mu \mathrm{g} \mathrm{mL}^{-1}\right)$ medium at $37^{\circ} \mathrm{C}$ in a humidified atmosphere containing $5 \%$ of $\mathrm{CO}_{2}$. Every 3-4 days, the cells were subcultured according to the previously described method (Raudone et al., 2014) with a slight modification.

Measurement of hydrogen peroxide $\left(\mathrm{H}_{2} \mathrm{O}_{2}\right)$ production in the macrophage culture. In the indirect model, a murine macrophage $\mathrm{J} 774$ cell suspension $(3 \times$ 105 cells per $\mathrm{mL}$ ) was dispensed into 6 well plates with $1 \mathrm{~mL}$ medium for 2 hours (for the adherence of cells). After 2 hours, different concentrations of lycopene extract solution $(0.2$ and $1.2 \mu \mathrm{M})$ were added to the cell culture and incubated in a thermostat (at $37^{\circ} \mathrm{C}$ in a humidified atmosphere containing $5 \%$ of $\mathrm{CO}_{2}$ ). The control sample did not include lycopene extract, but was prepared under the same conditions. After $24 \mathrm{~h}$ of incubation, the medium with lycopene extract was removed; the cells were collected, carefully washed with a PBS buffer and centrifuged at $1000 \mathrm{rpm}$ for $5 \mathrm{~min}$ at $23^{\circ} \mathrm{C} . \mathrm{H}_{2} \mathrm{O}_{2}$ production in the macrophage culture was measured fluorimetrically using a Fluoroskan Ascent plate reader (Thermo Fisher Scientific) at the excitation of $544 \mathrm{~nm}$ and an emission of $590 \mathrm{~nm}$. The production of 
$\mathrm{H}_{2} \mathrm{O}_{2}$ was obtained by stimulating nicotinamide adenine dinucleotide phosphate (NADPH) oxidase with $30 \mu \mathrm{M}$ of arachidonic acid (ARA) and $10 \mu \mathrm{M}$ of phorbol-12myristate-13-acetate (PMA) in a medium containing $1 \mu \mathrm{M}$ of Amplex Red and $10 \mathrm{U} \mathrm{mL}^{-1}$ of horseradish peroxidase. Horseradish peroxidase uses Amplex Red as an electron donor for the reduction of $\mathrm{H}_{2} \mathrm{O}_{2}$ to water; the reaction product resorufin is a colourful and fluorescent component. The fluorescence signal was evaluated according to the calibration curve of $\mathrm{H}_{2} \mathrm{O}_{2}$ (nmol). A similar measurement procedure was performed for the direct evaluation of lycopene activity. The macrophage culture in measurement wells was directly affected by the concentrations $(0.2,1.2$ and $7 \mu \mathrm{M})$ of lycopene extract, and the production of $\mathrm{H}_{2} \mathrm{O}_{2}$ was measured fluorimetrically in a period of $15 \mathrm{~min}$ according to the previously described method (Raudone et al., 2014) with a slight modification. A selected concentration of lycopene corresponds to plasma-determined lycopene concentrations $-0.2-1.5 \mu \mathrm{M}$ in accordance with various authors (Schierle et al., 1997; Sarkar et al., 2012).

Statistical analysis. All experiments were replicated three times and the results were expressed as the means \pm standard deviations. Statistical analysis was performed using software SPSS, version 16.0 (USA). Data were analysed using one-way analysis of variance (ANOVA) followed by Duncan's test. The confidence interval was $95 \%(p<0.05)$.

\section{Results and discussion}

According to the results of the study, the tomato peel contains high levels of lycopene, more than five times higher compared to the pulp and seeds (Fig. 1). Similar findings were obtained in the previous studies (Sharma, Le Maguer, 1996; Urbonaviciene et al., 2012), confirming that biorefinery of tomato by-products for the recovery of valuable functional ingredients (primary lycopene) is an important task.

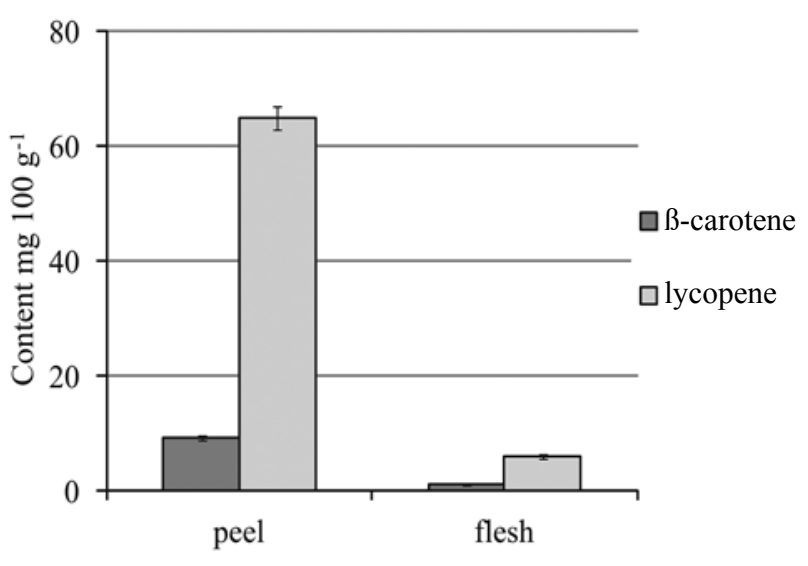

Part of tomatoes

Figure 1. Content of $\beta$-carotene and lycopene in tomato peel and flesh

In our previous study, the lycopene extraction procedure was optimized to obtain an extract (oleoresin) from by-products of tomato (cultivar 'Admiro' F1) in order to maximise the yield of concentration of lycopene cis-isomers (60\%) having an isomeric composition valued for its biological functions (Urbonaviciene, Viskelis, 2017). The optimal extraction process parameters of cislycopene isomers are $52^{\circ} \mathrm{C}$ temperature, at a pressure of $55 \mathrm{MPa}$ and $180 \mathrm{~min}$ extraction time. According to the results of the study, different technological parameters (temperature from $40^{\circ} \mathrm{C}$ to $60^{\circ} \mathrm{C}$ and the pressure of $55 \mathrm{MPa}$ ), influenced extract composition (Table 1). The investigated samples were as follows: No. $1\left(40^{\circ} \mathrm{C}\right.$ and $55 \mathrm{MPa})$, No. $2\left(50^{\circ} \mathrm{C}\right.$ and $\left.55 \mathrm{MPa}\right)$, No. $3\left(60^{\circ} \mathrm{C}\right.$ and $55 \mathrm{MPa})$ and No. $4\left(55^{\circ} \mathrm{C}\right.$ and $\left.55 \mathrm{MPa}\right)$. The total content of cis-lycopene isomer in the $\mathrm{SC}-\mathrm{CO}_{2}$ extract at optimal extraction conditions was $61.9 \%$. The extract obtained at optimal conditions was used for assessing the production of $\mathrm{H}_{2} \mathrm{O}_{2}$ in the murine macrophage $\mathrm{J} 774$ cell culture.

Table 1. Concentration of different cis-lycopene isomers in supercritical carbon dioxide $\left(\mathrm{SC}-\mathrm{CO}_{2}\right)$ extracts

\begin{tabular}{ccccccccc}
\hline Sample & Temperature $^{\circ} \mathrm{C}$ & trans- $^{2}$ & Total cis- & 15-cis & 13-cis & 9-cis & 7-cis & 5-cis \\
\hline No. 1 & 40 & $65.2 \pm 1.94 \mathrm{~b}$ & $34.8 \pm 0.92 \mathrm{a}$ & $2.9 \pm 0.09 \mathrm{a}$ & $3.7 \pm 0.07 \mathrm{a}$ & $10.7 \pm 0.29 \mathrm{a}$ & $6.4 \pm 0.15 \mathrm{~b}$ & $11.1 \pm 0.33 \mathrm{~b}$ \\
No. 2 & 50 & $40.7 \pm 0.85 \mathrm{a}$ & $59.3 \pm 1.71 \mathrm{~b}$ & $5.8 \pm 0.17 \mathrm{~b}$ & $8.3 \pm 0.19 \mathrm{~b}$ & $15.6 \pm 0.45 \mathrm{~b}$ & $10.5 \pm 0.40 \mathrm{a}$ & $19.1 \pm 0.53 \mathrm{c}$ \\
No. 3 & 60 & $68.2 \pm 0.16 \mathrm{~b}$ & $31.8 \pm 0.16 \mathrm{a}$ & $3.8 \pm 0.10 \mathrm{a}$ & $4.4 \pm 0.14 \mathrm{a}$ & $11.3 \pm 0.37 \mathrm{a}$ & $5.9 \pm 0.11 \mathrm{~b}$ & $6.4 \pm 0.12 \mathrm{a}$ \\
No. 4 & 52 & $38.1 \pm 0.13 \mathrm{a}$ & $61.9 \pm 0.16 \mathrm{~b}$ & $7.5 \pm 0.19 \mathrm{c}$ & $8.7 \pm 0.29 \mathrm{~b}$ & $16.8 \pm 0.59 \mathrm{~b}$ & $9.3 \pm 0.29 \mathrm{a}$ & $19.6 \pm 0.43 \mathrm{c}$ \\
\hline
\end{tabular}

Note. The numbers are means followed by standard deviations $(\mathrm{n}=3)$; means within a column with different superscript letters are significantly different $(p \leq 0.05)$.

The changes in colour values $\left(\mathrm{a}^{*}, \mathrm{~b}^{*}, \mathrm{~L}, \mathrm{C}\right.$ and $\mathrm{h}^{\circ}$ ) of the samples are shown in Table 2. This slight variation of the total colour can be mostly associated with the different concentration of total cis-lycopene isomers in the extracts. According to Rodriguez-Amaya (2001), cis-isomerization of the double bond of the chromophore in a carotenoid molecule causes a slight loss in colour, small hypsochromic shift (usually 2 to $6 \mathrm{~nm}$ for mono- cis), and hypochromic effect accompanied by the appearance of a cis peak in or near the ultraviolet region. The intensity of the cis band is greater as the cis double bond is nearer the centre of the molecule, which might explain the colour change.

In our study the production of ROS, i.e. $\mathrm{H}_{2} \mathrm{O}_{2}$ by macrophages was stimulated with ARA (arachidonic acid) and PMA (phorbol-12-myristate-13-acetate). The effect 
Table 2. The changes in colour values of supercritical carbon dioxide $\left(\mathrm{SC}-\mathrm{CO}_{2}\right)$ extracts

\begin{tabular}{cccccc}
\hline \multirow{2}{*}{ Sample } & \multicolumn{5}{c}{ Colour parameters } \\
\cline { 2 - 6 } & $a^{*}$ & $b^{*}$ & $L^{*}$ & $C$ & $\mathrm{~h}^{\circ}$ \\
\hline No. 1 & $4.22 \pm 0.11 \mathrm{~b}$ & $4.65 \pm 0.14 \mathrm{~b}$ & $24.55 \pm 1.10 \mathrm{~b}$ & $6.29 \pm 0.19 \mathrm{a}$ & $47.89 \pm 1.90 \mathrm{~b}$ \\
No. 2 & $4.95 \pm 0.14 \mathrm{a}$ & $4.85 \pm 0.09 \mathrm{a}, \mathrm{b}$ & $24.18 \pm 0.96 \mathrm{a}$ & $6.93 \pm 0.21 \mathrm{~b}$ & $43.94 \pm 1.75 \mathrm{a}$ \\
No. 3 & $3.74 \pm 0.13 \mathrm{c}$ & $4.96 \pm 0.11 \mathrm{a}$ & $24.56 \pm 0.81 \mathrm{~b}$ & $6.21 \pm 0.24 \mathrm{a}$ & $53.02 \pm 2.12 \mathrm{c}$ \\
No. 4 & $5.04 \pm 0.20 \mathrm{a}$ & $4.94 \pm 0.08 \mathrm{a}$ & $24.23 \pm 0.97 \mathrm{a}$ & $7.07 \pm 0.20 \mathrm{~b}$ & $44.30 \pm 1.76 \mathrm{a}$ \\
\hline
\end{tabular}

Note. $a^{*}$ - redness, $b^{*}$ - yellowness, $L^{*}$ - lightness, $C$ - chroma, $\mathrm{h}^{\circ}-$ hue angle; the numbers are means followed by standard deviations $(\mathrm{n}=3)$; means within a column with different superscript letters are significantly different $(p \leq 0.05)$.

of lycopene extract on the murine macrophage $\mathrm{J} 774$ cell culture was evaluated in an experimental model. PMA was chosen for the activation of ROS generation in macrophages; PMA induces protein kinase $(C)$, which activates NADPH oxidase and triggers oxidative burst. The results demonstrate that in this model the lycopene isomer extract at the concentrations of 0.2 and $1.2 \mu \mathrm{M}$ decreased the production of $\mathrm{H}_{2} \mathrm{O}_{2}$ by $11 \%$ and $43 \%$, respectively (Fig. 2).

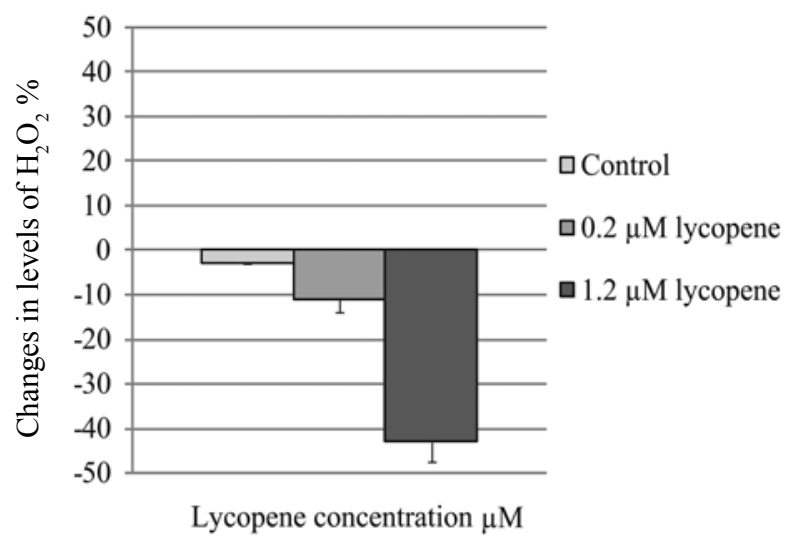

Expressed as mean $\pm \mathrm{SE}(\mathrm{n}=3)$

Figure 2. Indirect effect of lycopene extract on the production of hydrogen peroxide $\left(\mathrm{H}_{2} \mathrm{O}_{2}\right)$ in a murine J774 macrophage cell culture

The measurement procedure was also performed for the direct evaluation of lycopene activity which means that the cell culture in measurement wells was directly affected by different concentrations of lycopene extract. In direct model, the extract of lycopene isomers at concentrations of 0.2 and $1.2 \mu \mathrm{M}$ inhibit the production of $\mathrm{H}_{2} \mathrm{O}_{2}$ by $15-18 \%$, while concentrations exceeding the levels in plasma $(7 \mu \mathrm{M})$ promote the concentration of $\mathrm{H}_{2} \mathrm{O}_{2}$ by $20 \%$ (Fig. 3). In summary, the results suggest that lycopene can act on NADPH oxidase activity, affect its triggered generation of ROS and possess anti-inflammatory properties, as the ROS generated by NADPH oxidases participate in various inflammatory processes. The results indicate that the effects depend on the concentration of lycopene.

Literature suggests that cis-lycopene isomers have stronger in vitro antioxidant activity than the alltrans form (Müller et al., 2011). Based on literature

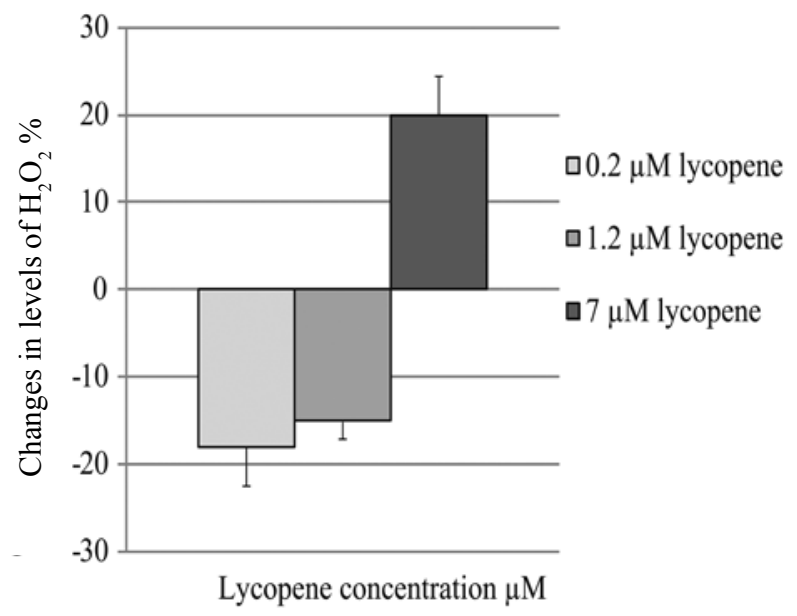

Figure 3. Direct effect of lycopene extract on the production of hydrogen peroxide $\left(\mathrm{H}_{2} \mathrm{O}_{2}\right)$ in murine macrophage $\mathrm{J} 744$ cell culture

data, the hypothesis is raised that lycopene can exert inhibition of carcinogenesis by several mechanisms: scavenging of ROS, enhancement of detoxification systems and suppression of cell cycle progression as a modulation of signal transduction pathways. Therefore, cis-lycopene isomers are regarded as having potentially better health benefits than trans-isomers. In this study, the anti-inflammatory and anti-proliferative properties of cis-lycopene isomers extract were examined for the first time.

Most commonly, in experiments with cells, oxidative damage induced by $\mathrm{H}_{2} \mathrm{O}_{2}$ is measured after preincubation of cells (of various types) with carotenoids, but not with lycopene or its cis-isomers (Kumar et al., 2013; Linnewiel-Hermoni et al., 2015). There are several interesting studies on the effect of lycopene on protection against oxidative damage. Zini et al. (2010) preincubated human sperm samples with 2 or $5 \mu \mathrm{mol} \mathrm{L} \mathrm{L}^{-1}$ lycopene before treating with $50 \mu \mathrm{mol} \mathrm{L} \mathrm{L}^{-1} \mathrm{H}_{2} \mathrm{O}_{2}$ and established protection against sperm DNA (measured with the comet assay) at higher concentration. According to Seo et al. (2009), lycopene protects against oxidative stress-induced cell death by preventing loss of DNA repair protein $\mathrm{Ku} 70$. The findings of the current research and also other studies suggest that cell culture studies might contribute useful information towards understanding the beneficial effects of carotenoids, especially their more biologically active forms, such as cis-lycopene isomers on human health. 
In conclusion, the in vitro experiments demonstrated that the investigated extract of lycopene isomer (depending on the concentration of lycopene) reduces the production of $\mathrm{H}_{2} \mathrm{O}_{2}$ in the murine macrophage J774 culture due to direct scavenging and possible effects on NADPH oxidase. The results demonstrate that the lycopene cis-isomer extract at the concentration of $1.2 \mu \mathrm{M}$ decreases the production of $\mathrm{H}_{2} \mathrm{O}_{2}$ by $43 \%$. The results provide significant evidence for cis-isomer-rich lycopene extract to be considered as a dietary supplement with potential activity for the prevention of ROS damage. The knowledge regarding the anti-inflammatory properties of lycopene $c i s$-isomer extract $(60 \%)$ could be useful in the development of food supplements or preparations with improved beneficial effects on human health.

\section{Conclusions}

1. The peel of tomato (cultivar 'Admiro' F1) contains about five times more lycopene than the pulp and seeds.

2. The dominant geometrical lycopene isomers in the supercritical carbon dioxide $\left(\mathrm{SC}-\mathrm{CO}_{2}\right)$ extract were 9-cis and 5-cis.

3. The total content of cis-lycopene isomers in the $\mathrm{SC}-\mathrm{CO}_{2}$ extract was $60 \%$ of the total lycopene content, showing that the $\mathrm{SC}-\mathrm{CO}_{2}$ extraction parameters could be modified to increase the concentration of cis-lycopene isomers in the extract. The use of concentrated carotenoid extracts from tomato by-products in traditional foods may improve the functional properties of the product while increasing the efficiency of the industrial processing of tomatoes.

4. The extract of isomerised lycopene $(60 \% \mathrm{cis}$ isomers from the total content of lycopene) decreased generation of reactive oxygene species (ROS). The extract of isomerised lycopene decreased production of hydrogen peroxide $\left(\mathrm{H}_{2} \mathrm{O}_{2}\right)$ by $43 \%$ in a $\mathrm{J} 774$ macrophages culture. The concentrated extracts of isomerised lycopene could be applied as pharmacological agents possessing antioxidant activities.

\section{Acknowledgments}

This work was supported by the grant from the Research Council of Lithuania, No. MIP-62/2015.

Received 10082017

Accepted 04012018

\section{References}

1. Azabou S., Abid Y., Sebii H., Felfoul I., Gargouri A., Attia H. 2016. Potential of the solid-state fermentation of tomato by products by Fusarium solani pisi for enzymatic extraction of lycopene. LWT-Food Science and Technology, 68: $280-287$.

https://doi.org/10.1016/j.lwt.2015.11.064
2. Bruno R. S., Wildman R. E. C., Schwartz S. J. 2007. Lycopene: food sources, properties and health. Wildman R. E. C. (ed.). Handbook of nutraceuticals and functional foods, p. 55-72.

3. Colle I., Van Buggenhout S., Van Loey A., Hendrickx M. 2010. High pressure homogenization followed by thermal processing of tomato pulp: influence on microstructure and lycopene in vitro bioaccessibility. Food Research International, 43 (8): 2193-2200. https://doi.org/10.1016/j.foodres.2010.07.029

4. Fernández-García E., Carvajal-Lérida I., Jarén-Galán M., Garrido-Fernández J., Pérez-GálvezA., Hornero-Méndez D. 2012. Carotenoids bioavailability from foods: from plant pigments to efficient biological activities. Food Research International, 46 (2): 438-450.

https://doi.org/10.1016/j.foodres.2011.06.007

5. Granato D., Branco G. F., Nazzaro F., Cruz A. G., Faria J. A. 2010. Functional foods and nondairy probiotic food development: trends, concepts, and products. Comprehensive Reviews in Food Science and Food Safety, 9 (3): 292-302.

https://doi.org/10.1111/j.1541-4337.2010.00110.x

6. Heymann T., Raeke J., Glomb M. A. 2013. Photoinduced isomerization of lycopene and application to tomato cultivation. Journal of Agricultural and Food Chemistry, 61 (46): 11133-11139. https://doi.org/10.1021/jf403694q

7. Holzapfel N. P., Holzapfel B. M., Champ S., Feldthusen J., Clements J., Hutmacher D. W. 2013. The potential role of lycopene for the prevention and therapy of prostate cancer: from molecular mechanisms to clinical evidence. International Journal of Molecular Sciences, 14 (7): 14620-14646. https://doi.org/10.3390/ijms140714620

8. Kaur S., Das M. 2011. Functional foods: an overview. Food Science and Biotechnology, 20 (4): 861-875. https://doi.org/10.1007/s10068-011-0121-7

9. Korhonen H. 2002. Technology options for new nutritional concepts. International Journal of Dairy Technology, 55 (2): 79-88.

https://doi.org/10.1046/j.1471-0307.2002.00050.x

10. Kumar S. R., Hosokawa M., Miyashita K. 2013. Fucoxanthin: a marine carotenoid exerting anti-cancer effects by affecting multiple mechanisms. Marine Drugs, 11 (12): 5130-5147. https://doi.org/10.3390/md11125130

11. Lenucci M. S., Caccioppola A., Durante M., Serrone L., Leonardo R., Piro G., Dalessandro G. 2010. Optimisation of biological and physical parameters for lycopene supercritical $\mathrm{CO}_{2}$ extraction from ordinary and highpigment tomato cultivars. Journal of the Science of Food and Agriculture, 90 (10): 1709-1718.

https://doi.org/10.1002/jsfa.4006

12. Linnewiel-Hermoni K., Khanin M., Danilenko M., Zango G., Amosi Y., Levy J., Sharoni Y. 2015. The anticancer effects of carotenoids and other phytonutrients resides in their combined activity. Archives of Biochemistry and Biophysics, 572: 28-35.

https://doi.org/10.1016/j.abb.2015.02.018 
13. Lobo V., Patil A., Phatak A., Chandra N. 2010. Free radicals, antioxidants and functional foods: Impact on human health. Pharmacognosy Reviews, 4 (8): 118. https://doi.org/10.4103/0973-7847.70902

14. McGuire R. G. 1992. Reporting of objective color measurements. HortScience, 27 (12): 1254-1255.

15. Müller L., Goupy P., Fröhlich K., Dangles O., CarisVeyrat C., Böhm V. 2011. Comparative study on antioxidant activity of lycopene (Z)-isomers in different assays. Journal of Agricultural and Food Chemistry, 59 (9): 4504-4511. https://doi.org/10.1021/jf1045969

16. Perretti G., Troilo A., Bravi E., Marconi O., Galgano F., Fantozzi P. 2013. Production of a lycopene-enriched fraction from tomato pomace using supercritical carbon dioxide. The Journal of Supercritical Fluids, 82: 177-182. https://doi.org/10.1016/j.supflu.2013.07.011

17. Poojary M. M., Passamonti P. 2015. Extraction of lycopene from tomato processing waste: kinetics and modelling. Food Chemistry, 173: 943-950. https://doi.org/10.1016/j.foodchem.2014.10.127

18. Raudone L., Bobinaite R., Janulis V., Viskelis P., Trumbeckaite S. 2014. Effects of raspberry fruit extracts and ellagic acid on respiratory burst in murine macrophages. Food and Function, 5 (6): 1167-1174. https://doi.org/10.1039/C3FO60593K

19. Rodriguez-Amaya D. B. 2001. A guide to carotenoid analysis in foods. Washington, USA, p. 1-60.

20. Sarkar P. D., Gupt T., Sahu A. 2012. Comparative analysis of lycopene in oxidative stress. The Journal of the Association of Physicians of India, 60: 17-19.

21. Schierle J., Bretzel W., Bühler I., Faccin N., Hess D., Steiner K., Schüep W. 1997. Content and isomeric ratio of lycopene in food and human blood plasma. Food Chemistry, 59 (3): 459-465.

https://doi.org/10.1016/S0308-8146(96)00177-X

22. Seo J. Y., Masamune A., Shimosegawa T., Kim H. 2009. Protective effect of lycopene on oxidative stress-induced cell death of pancreatic acinar cells. Annals of the New York Academy of Sciences, 1171 (1): 570-575. https://doi.org/10.1111/j.1749-6632.2009.04712.x

23. Shahidi F. 2009. Nutraceuticals and functional foods: whole versus processed foods. Trends in Food Science and Technology, 20 (9): 376-387. https://doi.org/10.1016/j.tifs.2008.08.004

24. Sharma S. K., Le Maguer M. 1996. Lycopene in tomatoes and tomato pulp fractions. Italian Journal of Food Science, 8 (2): 107-113.

25. Silva A. F., de Melo M. M., Silva C. M. 2014. Supercritical solvent selection $\left(\mathrm{CO}_{2}\right.$ versus ethane) and optimization of operating conditions of the extraction of lycopene from tomato residues: innovative analysis of extraction curves by a response surface methodology and cost of manufacturing hybrid approach. The Journal of Supercritical Fluids, 95: 618-627.

https://doi.org/10.1016/j.supflu.2014.09.016

26. Urbonaviciene D., Viskelis P. 2017. The cis-lycopene isomers composition in supercritical $\mathrm{CO}_{2}$ extracted tomato by-products. LWT-Food Science and Technology, 85: 517-523.

https://doi.org/10.1016/j.lwt.2017.03.034
27. Urbonaviciene D., Viskelis P., Viskelis J., Jankauskiene J., Bobinas C. 2012. Lycopene and $\beta$-carotene in non-blanched and blanched tomatoes. Journal of Food, Agriculture and Environment, 10 (2): 142-146.

28. Urbonaviciene D., Bobinaite R., Bobinas C., Rubinskiene M., Viskelis J., Viskelis P. 2017. Stability and isomerisation of lycopene in oil-based model system during accelerated shelf-life storage. Proceedings of the $11^{\text {th }}$ Baltic conference Food Science and Technology in a Changing World. Jelgava, Latvia, p. 150-153. https://doi.org/10.22616/foodbalt.2017.034

29. Urbonavičienè D., Bobinaitė R., Viškelis J., Viškelis P., Bobinas Č. 2015. Characterisation of tomato juice and different tomato-based juice blends fortified with isomerised lycopene extract. Proceedings of the $7^{\text {th }}$ international scientific conference Rural Development 2015. Aleksandras Stulginskis University, Lithuania, p. $1-6$. https://doi.org/10.15544/RD.2015.029

30. Viskelis P., Rubinskienė M., Bobinaitė R., Dambrauskienė E. 2010. Bioactive compounds and antioxidant activity of small fruits in Lithuania. Journal of Food, Agriculture and Environment, 8 (3-4): 259-263.

31. Wiernsperger N. F. 2003. Oxidative stress as a therapeutic target in diabetes: revisiting the controversy. Diabetes and Metabolism, 29 (6): 579-585. https://doi.org/10.1016/S1262-3636(07)70072-1

32. Zini A., San Gabriel M., Libman J. 2010. Lycopene supplementation in vitro can protect human sperm deoxyribonucleic acid from oxidative damage. Fertility and Sterility, 94 (3): 1033-1036. https://doi.org/10.1016/j.fertnstert.2009.04.004 
ISSN 1392-3196 / e-ISSN 2335-8947

Zemdirbyste-Agriculture, vol. 105, No. 1 (2018), p. 63-70

DOI $10.13080 / \mathrm{z}-\mathrm{a} .2018 .105 .009$

\title{
Funkcionaliojo maisto ingredientų išgavimas iš pomidorų šalutinių perdirbimo produktų
}

\author{
D. Urbonavičienè $\dot{1}^{1}$ R. Bobinaité ${ }^{1}$, S. Trumbeckaitè $\dot{2}^{2,3}$, L. Raudoné2 $\dot{2}^{2}$ V. Janulis ${ }^{2}$, \\ Č. Bobinas ${ }^{1}$, P. Viškelis ${ }^{1}$
}

${ }^{1}$ Lietuvos agrarinių ir miškų mokslų centro Sodininkystès ir daržininkystès institutas

${ }^{2}$ Lietuvos sveikatos mokslų universiteto Medicinos akademija

${ }^{3}$ Lietuvos sveikatos mokslų universiteto Neuromokslų institutas

\section{Santrauka}

Augalininkystès produktų perdirbimo šalutiniai produktai gali būti funkcionaliojo maisto sudedamųjų dalių šaltiniai, kurie yra komerciškai svarbūs, siekiant sumažinti atliekų kiekį, taip pat pagerinti procesų ekonominị efektyvumą, sukuriant pridètinę vertę turinčius ingredientus. Šiuo tikslu buvo išbandyta ir pritaikyta ekstrakcijos superkriziniu anglies dioksidu (angl. SC- $\mathrm{CO}_{2}$ ) technologija, siekiant gauti didesnès pridètinès vertès ingredientus iš veislès 'Admiro' F1 pomidorų šalutinių perdirbimo produktų (žievelès, sèklų ir nedidelio kiekio minkštimo). Buvo optimizuotas didesnès pridėtinès vertès ingredientų ekstrakcijos procesas (oleorezinas su $60 \%$ cis-likopeno izomerų koncentracija) ir ištirtas antioksidacinis aktyvumas išgauto ekstrakto ląstelių kultūroje.

Optimaliomis sąlygomis (temperatūra $-52^{\circ} \mathrm{C}$, slègis - $55 \mathrm{MPa}$, ekstrakcijos laikas - $180 \mathrm{~min}$ ) išgautas ekstraktas ivertintas nustatant sumines likopeno ir likopeno izomerų (15-cis-likopeno, 13-cis-likopeno, 9-cis-likopeno, 7-cislikopeno, trans-likopeno bei 5-cis-likopeno) koncentracijas ir likopeno cis-izomeru ekstrakto antioksidacines savybes, vandenilio peroksido $\left(\mathrm{H}_{2} \mathrm{O}_{2}\right)$ generaciją matuojant pelès makrofagų J774 ląstelių kultūroje.

Tyrimo rezultatai parodè, kad pomidorų šalutinių perdirbimo produktų (žievelių, sẻklų ir nedidelio kiekio minkštimo) superkrizinès ekstrakcijos $\mathrm{CO}_{2}$ oleorezinas yra potencialus cis-likopeno izomerų (koncentracija siekia $60 \%$ ) šaltinis, turintis plačias pritaikymo galimybes maisto ir farmacijos pramonejje.

Reikšminiai žodžiai: antioksidantas, likopenas, lipofilinis ekstraktas, Lycopersicon esculentum, trans/cisizomerai. 